\title{
In Vitro Evaluation of the Retention of Zirconia-Based Ceramic Posts Luted with Glass Ionomer and Resin Cements
}

\author{
Shivaughn MARCHAN ${ }^{1}$ \\ Larry COLDERO ${ }^{1}$ \\ Robert WHITING ${ }^{2}$ \\ Salvacion BARCLAY ${ }^{3}$ \\ ${ }^{1}$ Department of Restorative Dentistry, School of Dentistry, University of the West Indies, \\ EWMSC, Champs Fleurs, Trinidad and Tobago \\ ${ }^{2}$ Department of Physics, School of Natural Sciences, University of the West Indies, St. Augustine, Trinidad and Tobago \\ ${ }^{3}$ Department of General Dentistry, School of Dentistry, University of the West Indies, \\ EWMSC, Champs Fleurs, Trinidad and Tobago
}

\begin{abstract}
The retention of zirconia-based ceramic posts (CosmoPost system) luted with glass ionomer and resin cements was evaluated. Thirtytwo extracted, caries-free, unrestored teeth were selected and stored in chlorhexidine and water solution. The teeth were endodontically treated and randomly assigned to two groups $(\mathrm{n}=16)$. Each tooth was decoronated and prepared to a depth of $10.0 \mathrm{~mm}$ from root surface to receive a $1.4 \mathrm{~mm}$ diameter zirconium dioxide post. Each group had posts cemented with either glass ionomer cement (Fuji I) or resin cement (Variolink II). The post/teeth specimens were embedded in resin blocks and subjected to tensile testing. The tensile force required to dislodge the cemented posts in a tensile testing machine was recorded. The mean stress values of both groups were analyzed for statistical differences using ANOVA and Student's t-test. Significance level was set at 5\%. Mean peak forces at failure (N) and standard deviation for the tested cements were the following: Fuji I = $121.8( \pm 17.4)$ and Variolink II $=228.1$ ( \pm 36.8$)$. Posts luted with the resin cement presented statistically significant higher tensile bond strength than those retained with glass ionomer ( $\mathrm{p}<0.05$ ). It may be concluded that zirconia posts cemented with resin-based cement (Variolink II) failed at statistically significant higher values compared to those cemented with glass ionomer cement (Fuji I). Regardless of the cement type, the posts failed adhesively at the cement/post interface when subjected to a tensile force.
\end{abstract}

Key Words: posts, tensile testing, zirconia ceramics, resin cement, glass ionomer cement

\section{INTRODUCTION}

The only function of an endodontic post is to retain the core to facilitate a final cuspal coverage restoration. Therefore, the ability of a cement to retain a post, particularly a passive post, will greatly influence the success of the restoration. Design, length, surface configuration and type of endodontic post all play a major role in the behavior of the post/tooth complex (1).

Failure of the luting cement may lead to post failure that includes loosening of the post or root fracture. It has been postulated that when the cement lute fails the fulcrum point moves in an apical direction. This can increase the lever arm and magnify stresses, leading to further degradation of the cement and an increase in apical stress, which may cause root fracture $(1,2)$.

CosmoPost (Ivoclar Vivadent, Leicester, UK) is an yttrium stabilized zirconium dioxide ceramic post system. It is a passive, smooth-sided post that is parallel in the coronal two thirds and tapered in the apical third of its design. Zirconium dioxide ceramic post systems have been shown to improve aesthetics of all ceramic crowns when compared to their metallic and carbon 
fibre counterparts (3).

Zirconia posts are normally luted with resin luting cements. However, it has been shown that bonded posts prove difficult to remove and are associated with a concurrent undesirable increase in temperature (4). Despite their satisfactory clinical performance, glass ionomer luting cements have been shown to fail at lower tensile forces compared to their resin counterparts when used to lute metallic post systems (5). Thus glass ionomer cements may be a viable clinical alternative for luting zirconia posts while allowing less difficult removal if the need arises.

Several in vitro investigations have been conducted to investigate the retention of posts in nonvital teeth and compare different types of posts and luting cements (6). The purpose of this study was to compare the retentive values of CosmoPosts cemented with two types of luting agents: a glass ionomer and a resin-based cement.

\section{MATERIAL AND METHODS}

Thirty-two extracted human, single rooted, caries-free teeth were selected and stored in a solution of distilled water and $0.05 \%$ sterile chlorhexidine in a 2:1 ratio. All teeth were endodontically instrumented using a modified, double-flare, crown-down technique. Thereafter, teeth were decoronated $2.0 \mathrm{~mm}$ superior to the highest point of the cementoenamel junction. A 1.4 mm diameter CosmoPost drill was used to prepare post spaces to a depth of $10.0 \mathrm{~mm}$ while using distilled water irrigation to reduce heat generation. Teeth were randomly assigned to two experimental groups $(\mathrm{n}=16)$ and returned to the distilled water/chlorhexidine solution until required.

A pilot study showed that application of the vice grip of the tensile testing apparatus produced microcracks on the post surface. Hence, the portion of the CosmoPost protruding out of the root was embedded with poly methyl methacrylate to avoid compromising the physical properties of the post during tensile testing.

The $1.4 \mathrm{~mm}$ CosmoPost root bur was used to drill a post space of $11.0 \mathrm{~mm}$ in a block of set Paris plaster. The CosmoPost was seated in this prepared post space allowing the coronal $9.0 \mathrm{~mm}$ of the post to be protruding from the plaster. Plastic tubing $(5 \mathrm{~mm}$ diameter and $13 \mathrm{~mm}$ length) was centered around the protruding coronal aspect of the post to act as a matrix. Poly methyl methacrylate (acrylic) resin (Fas-Tray,
Harry J Bosworth Company, Stokie, IL, USA) was mixed in a ratio of $15 \mathrm{~mL}$ liquid:25g powder and poured into the tubing and allowed to set, after which the tubing was removed. The discrepancy between the post space preparations in the teeth and the Paris plaster allowed a $1.0 \mathrm{~mm}$ gap between the post/acrylic complex and the root surface.

Prior to cementing the CosmoPost/acrylic complex, they were trial seated to ensure complete seating to a depth of $10.0 \mathrm{~mm}$. Afterwards, each post space was irrigated with $5 \mathrm{~mL} 15 \%$ disodium ethylenediaminetetraacetate (EDTA) solution followed by $5 \mathrm{~mL}$ of distilled water and thoroughly dried with paper points. The part of the post to be cemented was steam cleaned for $15 \mathrm{~s}$ to remove any plaster residues.

CosmoPosts were cemented into the post spaces with either a glass ionomer luting cement [Fuji I (GC Corporation, Tokyo, Japan)] ( $\mathrm{n}=16)$ or a resin-based luting cement [Variolink II (Ivoclar Vivadent)] $(\mathrm{n}=16)$.

For posts luted with Fuji I glass ionomer, post space was rinsed with distilled water for $15 \mathrm{~s}$ and dried with paper points. One drop of liquid was mixed with one scoop of powder for $60 \mathrm{~s}$ and the material was applied to the post space walls with size 2 lentulo-spiral filler (Dentsply, Maillefer, Tulsa, UK). The post was seated into the canal, excess cement was removed from the root face using a sable brush and apical pressure applied to the post until setting occurred.

For posts luted with Variolink II resin cement, the post space was etched with $37 \%$ phosphoric acid (Total Etch; Ivoclar Vivadent) for $15 \mathrm{~s}$, rinsed with distilled water for $15 \mathrm{~s}$ and dried with paper points. Syntac primer (Ivoclar Vivadent) was applied to the dentin walls of the post space and left in-situ for $15 \mathrm{~s}$. A layer of Syntac adhesive (Ivoclar Vivadent) was applied and left in-situ for $10 \mathrm{~s}$. Low viscosity resin base and catalyst were mixed in a 1:1 ratio and applied to post space walls with size 2 lentulo-spiral filler (Dentsply, Maillefer). The post was seated into the canal, excess cement was removed using a sable brush and apical pressure was applied to the post until setting occurred. The liquid glycerin strip supplied with the Variolink II kit was placed around the root surface to exclude oxygen until setting was completed.

Thereafter, each tooth/post complex was embedded in individual cylinders of polymethyl methacrylate with the aid of a dental surveyor to ensure that the external surface of the post/acrylic complex 
was positioned parallel to the external surface of the embedding resin (Fig. 1). After setting of the embedding resin, the specimens were stored in $100 \%$ relative humidity for 1 week before tensile testing.

The specimens were placed into a testing jig mounted in a tensometer (JJ Instruments, Inc., Southampton, UK) (Fig. 2). The acrylic surrounding the post was gripped in the vice of the machine and a tensile force was applied at a crosshead speed of 1.0 $\mathrm{mm} / \mathrm{min}$ until tensile failure occurred. The peak tensile forces $(\mathrm{N})$ required to dislodge the posts were recorded. The mean stress values of both groups were analyzed for statistical differences using ANOVA and Student's t-test $(\mathrm{p}=0.05)$. The failed specimens were examined using a stereomicroscope at X6 magnification to determine the mode of failure.

\section{RESULTS}

Mean peak forces at failure (N) and standard deviation for the tested cements were as follows: Fuji I $=121.8( \pm 17.4)$ and Variolink II $=228.1( \pm 36.8)$.

Posts luted with the resin cement presented statistically significant higher tensile bond strength than those retained with glass ionomer $(\mathrm{p}<0.05)$.

Stereomicroscopic examination revealed that none of the failed posts had any cement remnants.

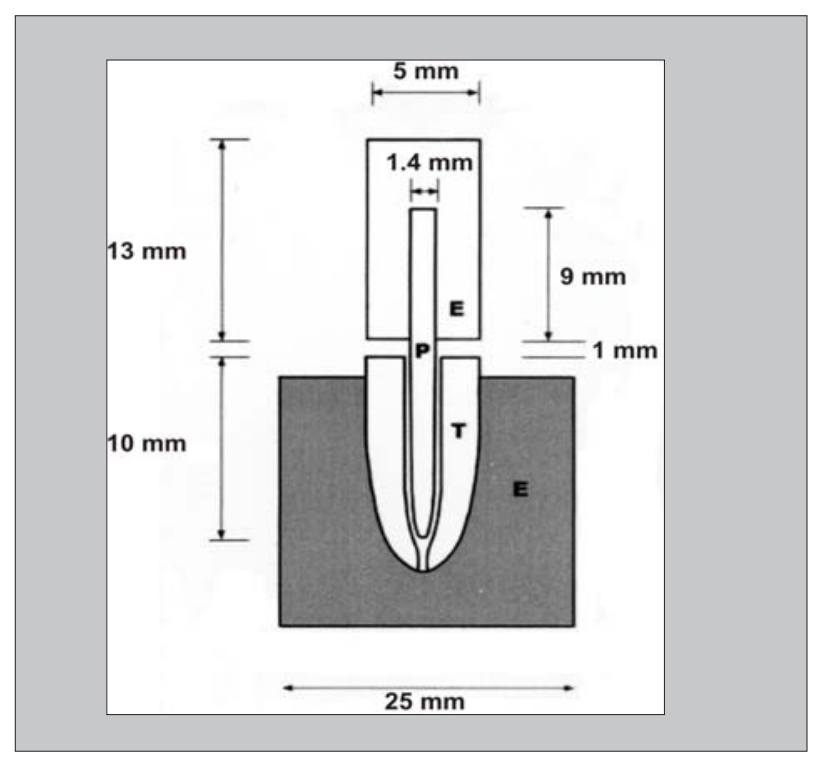

Figure 1. Schematic drawing showing specimen components. $\mathrm{P}=$ post; $\mathrm{E}=$ embedding resin; $\mathrm{T}$ = tooth.

\section{DISCUSSION}

The use of extracted human teeth in in vitro studies presents mechanical and anatomical variables. Despite these drawbacks, the use of natural teeth in the evaluation of post systems has been considered acceptable by investigators in this field (7). The group sample size was in agreement with that used in studies of a similar nature (8). The teeth were stored in a chlorhexidine/ distilled water solution to prevent bacterial overgrowth during periods of storage.

The modified, double-flare crown-down (with balanced force) technique used to prepare each tooth is both very efficient and is associated with the least amount of canal transportation $(9,10)$.

The use of $15 \%$ EDTA solution to irrigate the post space facilitated the removal of the loosely adherent smear layer formed during endodontic and post space preparation. Studies have shown that removal of this layer increases bond strength of restorative materials to dentin (11).

Zirconia ceramics exhibit stress-induced martensitic-like transformation, which means that crack propagation is prevented because of change of the tetragonal grain into a larger monoclinic grain (12). Even though the propensity for crack propagation in the zirconia-based CosmoPost system is less than for

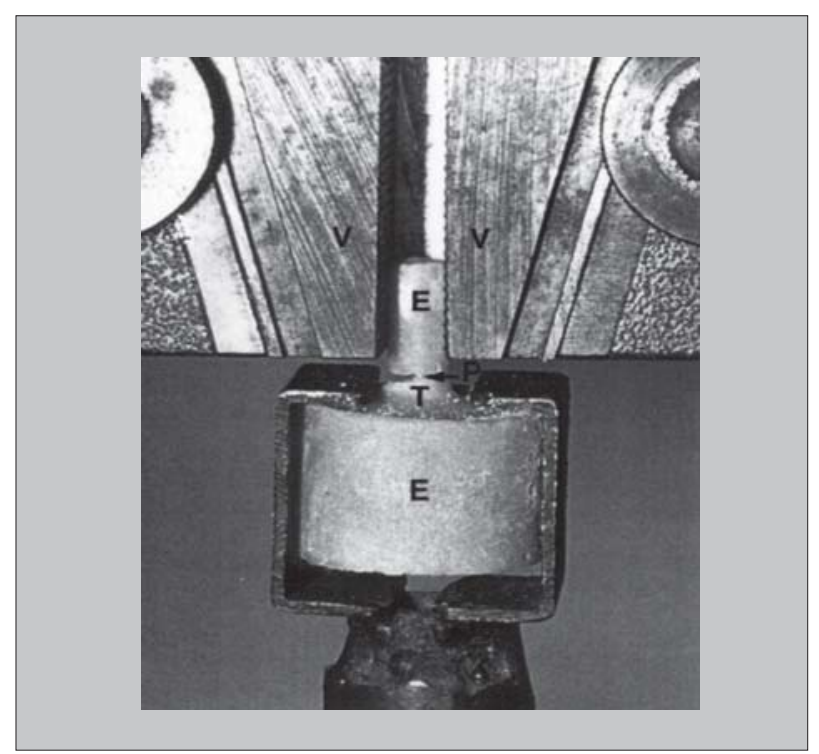

Figure 2. Specimen gripped in the tensile testing jig. $\mathrm{P}=$ post; $\mathrm{E}=$ embedding resin; $\mathrm{T}=$ tooth; $\mathrm{V}=$ tensometer vice grip. 
conventional ceramics, the pilot study demonstrated that cracks were evident when the post was gripped in the vice of the tensile testing machine. Therefore, it was decided to have the uncemented portion of the post embedded in poly methyl methacrylate resin to facilitate tensile testing.

The use of a low powder-to-liquid ratio to embed both the posts and the teeth aimed to allow maximum polymerization shrinkage, thus preventing early failure between the acrylic and posts or teeth during tensile testing. The high temperatures associated with the polymerization reaction of polymethyl methacrylate may have adversely affected the bond strengths of both luting cements used.

The $1.0 \mathrm{~mm}$ space between the post/acrylic complex and the cut root face ensured that the acrylic was not inadvertently luted to the root face, which would have contributed to an increased peak stress failure.

The use of the surveyor to embed the tooth/post complex was critical, as this allowed the tensile force to be applied in an axial direction eliminating any diagonal vector forces. A pilot study revealed that any deviation in the angulation between the post/tooth complex and the external surface of the embedding resin resulted in either fracture of the post just above the root surface or unusually high peak failure forces.

The lack of cement remnants on the failed posts clearly suggests adhesive failure at the cement/post interface. Studies have shown lack of a long-term durable chemical bond between resin cements and zirconia ceramics (13). Any cement used to lute such posts would rely on micromechanical retention provided by sandblasting the posts. Zirconia ceramics have high Vickers hardness (400 VHN). Because of its relatively high hardness, sandblasting of CosmoPosts produces only minimal undercuts on post surface (13), which reduces the potential micromechanical retention with a detrimental effect on bond strength. This would explain the adhesive failure between the post and cement as opposed to cohesive failure within the cement or adhesive failure between the cement and root dentin.

Smear layer removal with 15\% EDTA solution increase luting cement penetration into the dentinal tubules (particularly resin cements), which would produce higher bond strengths than those obtained between cement and post surface.

Statistical analysis clearly showed significant difference in peak failure values between posts luted with resin and glass ionomer cements. The higher values of the resin luting cement can be attributed to its better tensile and shear strength $(14,15)$. Both cements rely on micromechanical retentive features on the post surface whereby material tags fit into the sandblasted surface. Failure therefore depends on the mechanical properties of the material as opposed to actual bond strength between the luting agent and post.

The mechanical properties of luting cements are an important criterion when selecting a luting cement. The probability of early tensile failure is reduced with use of stronger cements hence increasing the chance of clinical success (15). However, if endodontic retreatment is indicated and post removal is required, a luting cement that exhibits lower tensile and shear properties may be better suited for this clinical situation.

From the findings of this study, it may be concluded that zirconia posts cemented with resinbased cement (Variolink II) failed at significantly higher values compared to those cemented with glass ionomer cement (Fuji I). Regardless of the cement type, the posts failed adhesively at the cement/post interface when subjected to a tensile force.

\section{RESUMO}

Este estudo avaliou a retenção de pinos intra-radiculares cerâmicos à base de zircônia (CosmoPost system) fixados com cimento de ionômero de vidro ou resinoso. Trinta e dois dentes extraídos, livres de cárie e não-restaurados foram selecionados e armazenados em solução de clorexidina e água. Os dentes foram submetidos a tratamento endodôntico e distribuídos aleatoriamente em dois grupos $(n=16)$. Cada dente teve a coroa removida e um espaço protético de $1.0 \mathrm{~mm}$ de profundidade (medida a partir da superfície radicular) foi preparado para receber um pino de dióxido de zircônio com 1,4 mm de diâmetro. Cada grupo teve os pinos fixados com cimento de ionômero de vidro (Fuji I) ou cimento resinoso (Variolink II). Os conjuntos dente/pino foram incluídos em blocos de resina e submetidos a testes de tração. Foi utilizado um tensiômetro para registrar a força de tração necessária para deslocar os pinos cimentados. Os valores médios de tração de ambos os grupos foram analisados por ANOVA e pelo teste t de Student. O nível de significância foi fixado em $5 \%$. Foram obtidos os seguintes valores médios de tensão de ruptura $(\mathrm{N})$ e desviospadrão: Fuji I = 121,8 ( $\pm 17,4)$; Variolink II = 228,1 $( \pm 36,8)$. Os pinos fixados com cimento resinoso apresentaram maior resistência ao deslocamento do que aqueles fixados com cimento de ionômero de vidro, sendo esta diferença estatisticamente significante $(\mathrm{p}<0,05)$. Pode-se concluir que os pinos de zircônia cimentados com cimento resinoso (Variolink II) apresentaram falhas sob valores de tensão significativamente maiores que os registrados para os pinos cimentados com ionômero de vidro (Fuji I). 
Independente do tipo de cimento utilizado, os pinos apresentaram falhas adesivas na interface cimento/pino ao serem submetidos a esforços de tensão.

\section{ACKNOWLEDGEMENTS}

The authors would like to thank The University of the West Indies campus research and publication fund for providing funding for this research project (Grant CRP.3BE). We are also grateful to Mr. Paul Willmer, Ivoclar Vivadent, Leicester, UK for the donation of the CosmoPosts and Variolink cement kits, and Mr. Jonathon Knowles, Head, Department of Dental Biomaterials, Eastman Dental Institute, University College London for his technical advice on this project.

\section{REFERENCES}

1. Musikant BL, Cohen BI, Deutsch AS. Post design and the optimally restored endodontically treated tooth. Compend Contin Educ Dent 2003;24:788-792, 794-796.

2. Greenfield RS, Roydhouse RH, Marshall FJ, Schoner B. A comparison of two post systems under applied compressive shear loads. J Prosthet Dent 1989;61:17-24.

3. Vichi A, Ferrari M, Davidson CL. Influence of ceramic and cement thickness on the masking of various types of opaque posts. J Prosthet Dent 2000;83:412-417.

4. Satterhwaite JD, Stokes AN, Frankel NTN. Potential for temperature change during the application of ultrasonic vibration to intraradicular posts. Eur J Prosthodont Rest Dent 2003;11:51-56.
5. Duncan JP, Pameijer CH. Retention of parallel-sided titanium posts cemented with six luting agents: an in vitro study. J Prosthet Dent 1998;80:423-428.

6. Sen D, Poyrazaglu E, Tuncelli B. The retentive effects of prefabricated posts by luting cements. J Oral Rehabil 2004;31:585-589.

7. Hedlund SO, Johansson NG, Sjogren G. Retention of prefabricated and individually cast root canal posts in vitro. $\mathrm{Br}$ Dent J 2003;155-158.

8. Hagge MS, Wong DM, Lindemuth JS. Effect of three root canal sealers on the retentive strength of endodontic posts luted with a resin cement. Int Endod J 2002;35:372-378.

9. Saunders EM, Saunders WP. The challenge of preparing the curved root canal. Dent Update 1997;24:241-247.

10. Al-Omari MAO, Dunner PMH. Canal blockage and debris extrusion with eight preparation techniques. J Endodont 1995;21:154-158.

11. Alfredo E, Junior JR, Silva-Sousa Y, Sobrinho LO, Saquy PL, Sousa Neto MD. Evaluation of retention of post-core system cemented with different materials on dentine surfaces treated with EDTA or Er:YAG laser irradiation. Photomed Laser Surg 2005;23:36-40.

12. Tateishi T, Yunoki H. Research and development of advanced biocompatible materials and applications to the artificial hip joint. Bull Mech Eng 1987;45:1-9.

13. Kern M, Wegner SM. Bonding to zirconia ceramic: adhesion methods and their durability. Dent Mater 1998;14:64-71.

14. Li ZC, White SN. Mechanical properties of dental luting cements. J Prosthet Dent 1999;81:597-609.

15. White SN, Yu Z. Compressive and diametral tensile strengths of current adhesive luting agents. J Prosthet Dent 1993;69:568-572.

Accepted August 16, 2004 